\title{
Diffusion of chromium and impurity absorption in ZnS crystals
}

\author{
Yu.A.Nitsuk \\ I.Mechnikov National University, 2 Dvoryanskaya Str., \\ 65082 Odesa, Ukraine
}

Received September 18, 2012

\begin{abstract}
ZnS:Cr single crystals obtained by diffusion doping are investigated. The spectra of optical density in the range of energies $0.3-3.8 \mathrm{eV}$ are investigated. The chromium concentration in the studied crystals is determined using the magnitude of the shift of the absorption edge. Optical transitions determining the impurity absorption spectrum of $\mathrm{ZnS}: \mathrm{Cr}$ single crystals are identified. The diffusion profile of $\mathrm{Cr}$ impurity is determined by measuring the relative optical density of crystals in the visible spectral region. At first, the diffusivities of $\mathrm{Cr}$ in $\mathrm{ZnS}$ crystals are calculated for temperatures of 1170-1320 K. At $1270 \mathrm{~K}$, the diffusivity of $\mathrm{Cr}$ is $8 \cdot 10^{-10} \mathrm{~cm}^{2} / \mathrm{s}$.
\end{abstract}

\begin{abstract}
Методом диффузионного легирования получены монокристаллы ZnS:Cr. Исследованы спектры оптической плотности в области энергий 0.3-3.8 эВ. По величине смещения края поглощения определена концентрация хрома в исследуемых кристаллах. Идентифицированы оптические переходы, обуславливающие спектр примесного поглощения монокристаллов ZnS:Cr. Диффузионный профиль примеси хрома определен путем измерения относительной оптической плотности кристаллов в видимой области спектра. Впервые рассчитаны коэффициенты диффузии хрома в кристаллах ZnS при температурах 1170-1320 К. При $1270 \mathrm{~K}$ коэффициент диффузии хрома составляет $8 \cdot 10^{-10} \mathrm{~cm}^{2} / \mathrm{c}$.
\end{abstract}

\section{Introduction}

The zinc sulfide single crystals doped with chromium can be used as active media environments and passive gates for the mid infrared (IR) spectral region lasers. The effective laser generation in the spectral region $2.35 \mu \mathrm{m}$ has been realized in $\mathrm{ZnS}: \mathrm{Cr}$ crystals [1]. At the same time, in order to obtain efficient laser structures based on zinc sulphide, the chromium concentration should be no lower than $10^{19} \mathrm{~cm}^{-3}$. The emission realized in a laser is conditioned by the intracentre radiative transitions ${ }^{5} E(D) \rightarrow{ }^{5} T_{2}(D)$ between the lower excited state ${ }^{5} E(D)$ and the ground state ${ }^{5} T_{2}(D)$. These states of $\mathrm{Cr}^{2+}$ ion are most studied both in theory and experimental $[2,3]$. The high-energy states of $\mathrm{Cr}^{2+}$ ion are not yet known. The calculations of the high-energy states executed in a number of works $[4,5]$ are not confirmed by experimental researches [6]. Therefore the obtaining of ZnS:Cr crystals, research of their optical properties, identification of the nature of the high-energy states of $\mathrm{Cr}^{2+}$ ion is actual.

The purpose of this study is development of a method of diffusion doping of $\mathrm{ZnS}$ crystals with $\mathrm{Cr}$, identification of optical absorption spectra, and determination of $\mathrm{Cr}$ diffusivity in ZnS crystals.

In this investigation the procedure of diffusion doping, which allows one to obtain $\mathrm{ZnS}: \mathrm{Cr}$ single crystals with a specified concentration of $\mathrm{Cr}$ impurity. The concentration of chromium is determined by means of magnitude of the absorption edge shift. The structure of optical absorption spectra of $\mathrm{ZnS}: \mathrm{Cr}$ in visible and infrared wavelength regions is studied and identified. The calcu- 
lations of the energy states of $\mathrm{Cr}^{2+}$ ion in the zinc sulfide matrix are executed. Analysis of the relative optical density profiles in a visible region allowed to determine the diffusivity of chromium in ZnS crystals.

\section{Experimental}

The samples for study were obtained by diffusion doping with $\mathrm{Cr}$ of $\mathrm{ZnS}$ single crystals. The undoped crystals are obtained via free growth method on a single crystal ZnS (111) substrate. No polytypes were discovered in the crystals structure. The detailed description of this growth method and main characteristics of ZnS crystals are described in [7]. Selection of temperature profiles and design of the growth chamber excluded the possibility of a contact between the crystal and chamber walls. The dislocation density in the crystals was no higher than $10^{4} \mathrm{~cm}^{-2}$.

The crystals were doped by impurity diffusion from a metal $\mathrm{Cr}$ layer deposited on the crystal surface. Chromium was deposited on one of the large surfaces of a crystal plate $\left(10 \times 5 \times 1 \mathrm{~mm}^{3}\right)$ cut out parallel to $(111)$ plane. The chromium layer thickness was about $10 \mu \mathrm{m}$. The crystals were annealed in $\mathrm{He}+\mathrm{Ar}$ atmosphere at 1170-1320 K (see Table 1). The diffusion process was $10 \mathrm{~h}$ long.

Diffusion of $\mathrm{Cr}$ was performed under conditions in which the impurity concentration of admixture in the source remained virtually constant. In this case the solution of the Fick's diffusion equation for the one dimensional diffusion has the form

$$
C(x, t)=C_{0}\left(1-\operatorname{erf} \frac{x}{\sqrt{4 D t}}\right),
$$

where $C_{0}$ is the activator concentration at the surface, $D$ is the impurity diffusivity and the symbol "erf" denotes the error function (Gaussian function).

After annealing the crystals $\mathrm{ZnS}: \mathrm{Cr}$ were characterized by the presence of diffusion

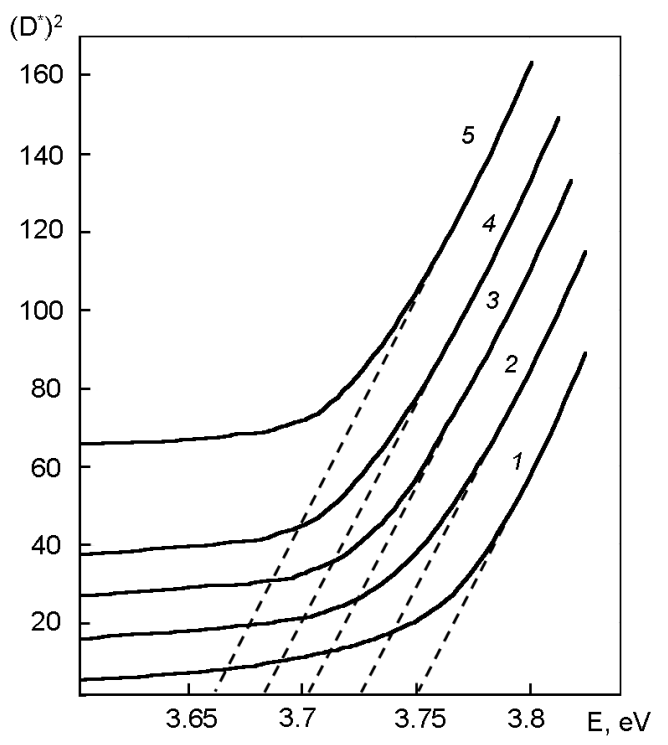

Fig. 1. Spectra of optical density of ZnS (1) and ZnS:Cr samples 2 (2), 3 (3), 4 (4) and 5 (5).

profile with a thickness increasing with the annealing temperature elevation. The profile color varied from colorless to yellow with the temperature increasing.

Optical density $D^{*}$ spectra were measured using MDR-6 monochromator with 1200, 600 and 325 grooves $/ \mathrm{mm}$ diffraction grates. The first grate was used to analyze the absorption spectra in the 3.8-1.2 eV photon energy range, the second, in the interval 1.2-0.6 eV one, and third, in the 0.6$0.3 \mathrm{eV}$ one. FEU-100 photomultiplier was used as a light flow receiver in the visible spectral region, while FR-1P photoresistor working in the alternating current mode in the IR region. The optical density spectra were measured at 77 and $293 \mathrm{~K}$. The optical windows of cryostat chamber used to study the optical density were of $3 \mathrm{~mm}$ diameter.

For measuring the diffusion profile of chromium impurity a thin plate of the crystal $(0.2-0.4 \mathrm{~mm})$ was cleaved in the plane parallel to the direction of the diffusion flux. The measurement of the profile of op-

Table 1. Optical characteristics of ZnS:Cr crystals in the absorption edge region

\begin{tabular}{||c|c|c|c|c||}
\hline Sample No. & Type of the crystal & $E_{g}, \mathrm{eV}$ & $\Delta E_{g}, \mathrm{meV}$ & $N, \mathrm{~cm}^{-3}$ \\
\hline 1 & ZnS starting & 3.75 & - & - \\
2 & ZnS:Cr, annealing 1170 K & 3.74 & 20 & $2 \cdot 10^{17}$ \\
3 & ZnS:Cr, annealing 1220 K & 3.71 & 40 & $2 \cdot 10^{18}$ \\
4 & ZnS:Cr, annealing 1270 K & 3.69 & 60 & $5 \cdot 10^{18}$ \\
5 & ZnS:Cr, annealing 1320 K & 3.66 & 90 & $2 \cdot 10^{19}$ \\
\hline \hline
\end{tabular}


tical density of Cr-doped crystals was performed using MF-2 microphotometer. This device allowed us to measure a magnitude of optical density with a step of $10 \mu \mathrm{m}$ in the direction of diffusion flux. In this case the integrated optical density was measured in the spectral range $2.8-2.4 \mathrm{eV}$.

\section{Analysis of the optical density spectra}

The spectra of optical density of undoped ZnS crystals at $77 \mathrm{~K}$ are characterized by an absorption edge with energy $3.75 \mathrm{eV}$ (Fig. 1, curve 1). In the range $0.30-3.6 \mathrm{eV}$, no features of the absorption spectra of the undoped crystals are found.

Doping crystals with chromium results in the absorption edge shift towards lower energies (Fig. 1, curves 2-5). The shift value increases with annealing temperature growth and it is conditioned by interimpurity Coulomb interaction. The band gap width variation $\Delta E_{g}$ (in meV) as a function of impurity concentration depending on concentration of introduced impurities is determined in [8] by the relation:

$$
\Delta E_{g}=2 \cdot 10^{5}\left(\frac{3}{\pi}\right)^{1 / 3} \frac{e N^{1 / 3}}{4 \pi \varepsilon_{0} \varepsilon_{s}},
$$

where $e-$ is electron charge, $N$ is impurity concentration in $\mathrm{cm}^{-3}, \varepsilon_{s}=8.3$ is $\mathrm{ZnS}$ dielectric constant. The concentration of chromium in the studied crystals was calculated from band gap width changing (see Table 1). The maximum concentration of chromium was $2 \cdot 10^{19} \mathrm{~cm}^{-3}$ for the crystals annealed at $1320 \mathrm{~K}$.

In the visible spectral region the spectra of optical density of ZnS:Cr crystals at $77 \mathrm{~K}$ is contain a series of poorly resolved lines (Fig. 2). Light absorption in this region increases as the chromium concentration growth. In the absorption spectrum of the lightly-doped ZnS:Cr crystals obtained at $1170 \mathrm{~K}$, twenty absorption lines can be distinguished, namely, at $3.31,3.17,3.08$, $3.0,2.94,2.85,2.69,2.65,2.59,2.54$, $2.48,2.40,2.28,2.21,2.14,2.09,2.0$, 1.88, 1.82, $1.76 \mathrm{eV}$ (Fig. 2, curve 1). With increase of the doping level the location of these lines remained unchanged (Fig. 2, curves 2-3). Studies of the optical density in the temperature range $77-300 \mathrm{~K}$ showed that location of these lines remained unchanged. Such behavior is characteristic for the absorption lines conditioned by the optical transitions of electrons within the impu-

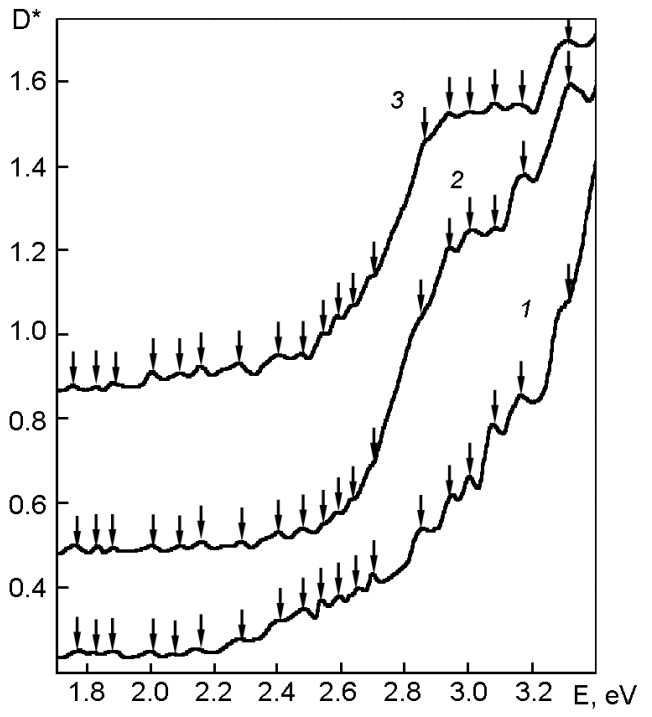

Fig. 2. Spectra of optical density of $\mathrm{ZnS}: \mathrm{Cr}$ crystals in the visible region. Samples (1) 2 , (2) 3 and (3) 4 .

rity ion limits [9]. In the Table 2 the energies of optical transitions and their identification in the limits of $\mathrm{Cr}^{2+}$ ion are given. This table is created on the basis of our experimental results and our calculations of $\mathrm{Cr}^{2+}$ ion energy states in ZnS lattice performed on the Tanabe-Sugano diagrams [10]. It is achieved the best accordance of experiment and theory at the parameters of the crystalline field of $\Delta=6100 \mathrm{~cm}^{-1}$ and $B=600 \mathrm{~cm}^{-1}$. Values of $\Delta$ and $B$ parameters correspond with the results of the calculations performed in [11].

In the IR-region the spectra of optical density of $\mathrm{ZnS}: \mathrm{Cr}$ crystals are characterized by the broad absorption bands at 1.36, 1.22 and $0.75 \mathrm{eV}$. The optical density of the crystals increased with chromium concentration growth. The location of these bands was unchanged under the temperature varying from 77 to $300 \mathrm{~K}$ and chromium temperature varying. This absorption bands was observed before in $[5,6,12]$. The first absorption band is due to ${ }^{5} T_{2}(D) \rightarrow{ }^{3} T_{2}(H)$ transitions occurring in the limits of $\mathrm{Cr}^{2+}$ ion [5]. The absorption band at $1.22 \mathrm{eV}$ is related to ${ }^{5} T_{2}(D) \rightarrow{ }^{1} A_{1}(I)$ transitions (see Table 2). The absorption band at $0.75 \mathrm{eV}$ is related to the well studied $[5,12]$ transitions between ${ }^{5} T_{2}(D)$ ground state and ${ }^{5} E(D)$ first excited state of $\mathrm{Cr}^{2+}$ ions. At excitation by light corresponding to the high-energy intrinsic absorption region of $\mathrm{Cr}^{2+}$ ions intracenter emission ${ }^{5} E(D) \rightarrow{ }^{5} T_{2}(D)$ transitions were observed. 
Table 2. Optical transitions in the limits of $\mathrm{Cr}^{2+}$ ion

\begin{tabular}{|c|c|c|c|}
\hline $\begin{array}{c}\text { Line } \\
\text { No }\end{array}$ & $E_{\text {exp }}, \mathrm{eV}$ & $E_{c a l c}, \mathrm{eV}$ & Transition \\
\hline 1 & 3.31 & 3.32 & ${ }^{5} T_{2}(D) \rightarrow{ }^{1} E(G)$ \\
\hline 2 & 3.17 & 3.18 & ${ }^{5} T_{2}(D) \rightarrow{ }^{1} T_{2}(G)$ \\
\hline 3 & 3.08 & 3.07 & ${ }^{5} T_{2}(D) \rightarrow{ }^{3} E(D)$ \\
\hline 4 & 3.00 & 3.01 & ${ }^{5} T_{2}(D) \rightarrow{ }^{3} T_{1}(G)$ \\
\hline 5 & 2.94 & 2.97 & ${ }^{5} T_{2}(D) \rightarrow{ }^{3} T_{1}(G)$ \\
\hline 6 & 2.85 & 2.82 & ${ }^{5} T_{2}(D) \rightarrow{ }^{1} A_{2}(I)$ \\
\hline 7 & 2.69 & 2.69 & ${ }^{5} T_{2}(D) \rightarrow{ }^{3} T_{2}(D)$ \\
\hline 8 & 2.65 & 2.65 & ${ }^{5} T_{2}(D) \rightarrow{ }^{3} A_{1}(G)$ \\
\hline 9 & 2.59 & 2.62 & ${ }^{5} T_{2}(D) \rightarrow{ }^{1} T_{2}(I)$ \\
\hline 10 & 2.54 & 2.56 & ${ }^{5} T_{2}(D) \rightarrow{ }^{1} A_{1}(G)$ \\
\hline 11 & 2.48 & 2.51 & ${ }^{5} T_{2}(D) \rightarrow{ }^{1} E(I)$ \\
\hline 12 & 2.40 & 2.45 & ${ }^{5} T_{2}(D) \rightarrow{ }^{3} T_{1}(F)$ \\
\hline 13 & 2.28 & 2.28 & ${ }^{5} T_{2}(D) \rightarrow{ }^{3} E(G)$ \\
\hline 14 & 2.21 & 2.22 & ${ }^{5} T_{2}(D) \rightarrow{ }^{3} A_{2}(F)$ \\
\hline 15 & 2.14 & 2.14 & ${ }^{5} T_{2}(D) \rightarrow{ }^{1} T_{2}(I)$ \\
\hline 16 & 2.09 & 2.07 & ${ }^{5} T_{2}(D) \rightarrow{ }^{3} T_{2}(G)$ \\
\hline 17 & 2.00 & 2.00 & ${ }^{5} T_{2}(D) \rightarrow{ }^{3} T_{1}(P)$ \\
\hline 18 & 1.88 & 1.88 & ${ }^{5} T_{2}(D) \rightarrow{ }^{3} E(H)$ \\
\hline 19 & 1.82 & 1.83 & ${ }^{5} T_{2}(D) \rightarrow{ }^{3} T_{2}(F)$ \\
\hline 20 & 1.76 & 1.79 & ${ }^{5} T_{2}(D) \rightarrow{ }^{1} T_{1}(I)$ \\
\hline 21 & 1.36 & 1.36 & ${ }^{5} T_{2}(D) \rightarrow{ }^{3} T_{2}(H)$ \\
\hline 22 & 1.22 & 1.19 & ${ }^{5} T_{2}(D) \rightarrow{ }^{1} A_{1}(I)$ \\
\hline 23 & 0.75 & 0.75 & ${ }^{5} T_{2}(D) \rightarrow{ }^{5} E(D)$ \\
\hline
\end{tabular}

It should be noted that the absorption bands broadened with an increase of the crystals doping level. A similar broadening of the structure of the lines takes place in the absorption spectral in the visible region. This is apparently associated with manifestation of the impurity-impurity interaction of $\mathrm{Cr}^{2+}$ ions.

\section{Diffusion profile of chromium in ZnS crystals}

The presence of characteristic chromiumabsorption lines in the visible region of the spectrum indicates that it is possible to determine the impurity-diffusion profile by measuring the relative optical density $\left(\Delta^{*}\right)$. This quantity is a function of the coordinate $x$ in the direction of the diffusion flux and is defined by the expression

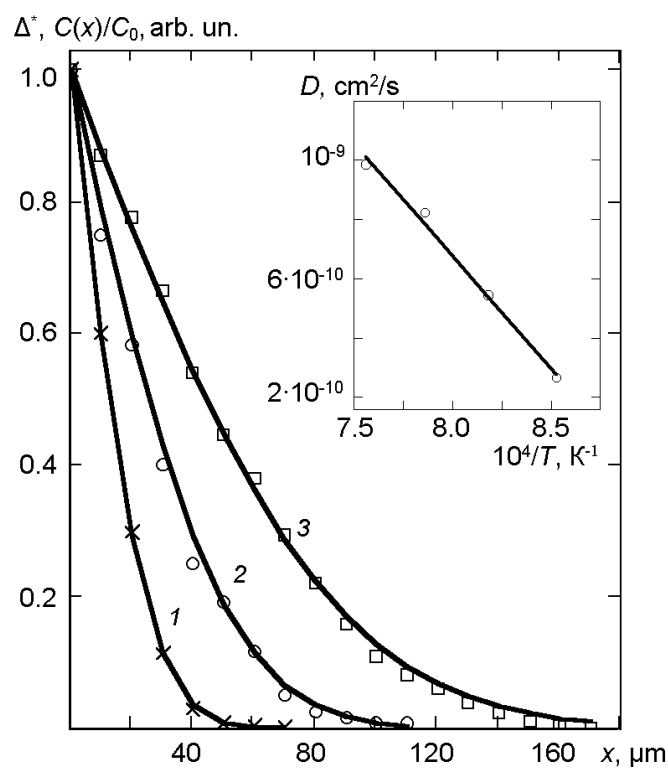

Fig. 3. Profiles of relative optical density (points in the curve) and diffusion profiles of $\mathrm{Cr}$ (solid lines) of ZnS:Cr crystals, samples (1) 3 , (2) 4 and (3) 5. The temperature dependence of the $\mathrm{Cr}$ diffusivity in $\mathrm{ZnS}$ crystals is in the inset.

$$
\Delta^{*}=\frac{D^{*}(x)-D^{*}(\infty)}{D^{*}(0)-D^{*}(\infty)},
$$

where $D^{*}(x)$ is the crystal's optical density as a function of the coordinate $x, D^{*}(0)$ is the optical density of the crystal in the surface layer with the coordinate $x=0$, and $D^{*}(\infty)$ is the optical density of the crystal in the region, where the chromium concentration is negligible (the crystal is not doped). The chosen definition of relative optical density makes it possible to compare the dependence $\Delta^{*}(x)$ with the impurity concentration profile $C(x) / C_{0}$ calculated by formula (1). By choosing the value of the diffusivity in Eq.(1), we managed to obtain good agreement between the relative optical density and chromium concentration profiles in the crystals (Fig. 3). The diffusivities of $\mathrm{Cr}$ in $\mathrm{ZnS}$ crystals at temperature 1170-1320 K were calculated similarly. The temperature dependence of diffusivity $D(T)$, presented in inset to Fig. 3, is described by Arrhenius equation

$$
D(T)=D_{0} \exp \left(-\frac{E}{k T}\right),
$$

where the factor $D_{0}=2 \cdot 2 \cdot 10^{-3} \mathrm{~cm}^{2} / \mathrm{s}$, while the activation energy of diffusion $E=1.62 \mathrm{eV}$. 
At the crystals annealing temperature of $1270 \mathrm{~K}$ the diffusivities of chromium is $8 \cdot 10^{-10} \mathrm{~cm}^{2} / \mathrm{c}$. This value is a few orders less than chromium diffusivity in $\mathrm{ZnSe}$ crystals, which we determined according to the procedure described in [13].

\section{Conclusions}

The study allows a number of conclusions. These are as follows: The method of chromium diffusion doping of $\mathrm{ZnS}$ single crystals was developed. The maximum concentration of chromium impurity determined by the shift of the absorption edge in $\mathrm{ZnS}: \mathrm{Cr}$ was $2 \cdot 10^{19} \mathrm{~cm}^{-3}$. The nature of absorption lines of $\mathrm{ZnS}: \mathrm{Cr}$ crystals in the visible and IR regions of the spectrum was identified. The diffusivities of chromium in $\mathrm{ZnS}$ crystals in the temperature range 1170-1320 K were calculated for the first time. Analysis of the temperature dependence $D(T)$ allowed us to determine the coefficients in Arrhenius equation: $D_{0}=2.2 \cdot 10^{-3}$ $\mathrm{cm}^{2} / \mathrm{s}$ and $E=1.62 \mathrm{eV}$. At $1270 \mathrm{~K}$ the diffusivity of $\mathrm{Cr}$ is $8 \cdot 10^{-10} \mathrm{~cm}^{2} / \mathrm{s}$.

\section{References}

1. I.T.Sorokina, E.Sorokin, S.Mirov et al., Opt. Lett., 27, 1040 (2002).

2. K.Graham, V.V.Fedorov, S.B.Mirov et al., Quant. Electron., 34, 8 (2004).

3. J.T.Vallin, G.A.Slack, S.Roberts, Phys. Rev.B, 2, 4313 (1970).

4. J.Kreissl, H.-J.Schulz, J.Cryst.Growth., 161, 239 (1996).

5. A.Zunger, Solid State Phys., 39, 276 (1986).

6. C.S.Kelley, F.Williams, Phys. Rev. B, 2, 3 (1970).

7. Yu.V.Korostelin, V.I.Kozlovsky, A.S.Nasibov, P.V.Shapkin, J.Cryst.Growth., 197, 449 (1999).

8. Yu.I.Ukhanov, Optical Properties of Semiconductors, Nauka, Moscow (1977) [in Russian].

9. V.F.Agekyan, Fiz. Tverd.Tela, 44, 1921 (2002).

10. J.E.Huheey, Inorganic Chemistry, Harper \& Row, New York (1970).

11. E.M.Wray, J.W.Allen, J.Phys.C: Solid State Phys., 4, 512 (1971).

12. M.G.Zhao, L.H.Xie, Mater. Sci. and Engin., B75, 72 (2000).

13. Yu.F.Vaksman, V.V.Pavlov, Yu.A.Nitsuk et al., Semiconductors, 39, 377 (2005).

\title{
Дифузія хрому i домішкове поглинання у кристалах ZnS
}

\begin{abstract}
Ю.A.Hiuук
Методом дифузійного легування отримані монокристали ZnS:Cr. Досліджено спектри оптичної густини в області енергій 0.3-3.8 eB. За величиною зсуву краю поглинання визначено концентрацію хрому у досліджуваних кристалах. Ідентифіковано оптичні переходи, що визначають спектр домішкового поглинання монокристалів ZnS:Cr. Дифузійний профіль домішки хрому визначався за вимірюваннями відносної оптичної густини кристалів у видимій області спектра. Вперше розраховано коефіцієнти дифузії хрому у кристалах ZnS при температурах 1170-1320 К. При 1270 К коефіцієнт дифузії хрому становить $8 \cdot 10^{-10} \mathrm{~cm}^{2} / \mathrm{c}$.
\end{abstract}

